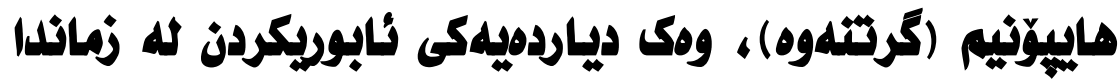

بهشى كيمياء، كؤليّى زانست، زانكوى رِايهرين، رِانيه، هـريّمى كوردستان، عيّراق.

صالج عبدالله بـابكر

salh.abdulla@uor.edu.krd

ناونيشانى ئهم تويَزَينهوهيه بوّ (هاييّونيم (كرتنهوه)، وهك دياردهيهكى ئابوريكردن له زماندا) تهرخانكراوه، ئابوريكردن

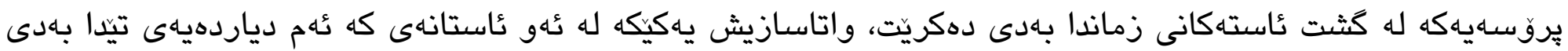
دهكريت، هاييقونيميش يهكيكه لهم يهيوهنييه واتاييانهى كه ثابوريكردنى تيدا بهرجاودهكويت. جونكه بريتييه له

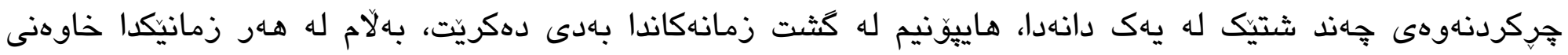
تايبهتمـهنديى خوّيانى.

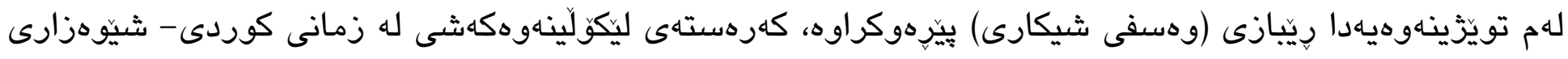
سليمانى - وهركيراوه.

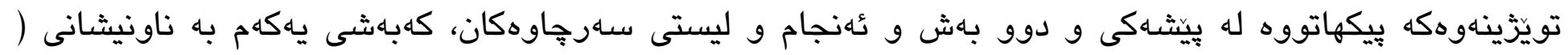

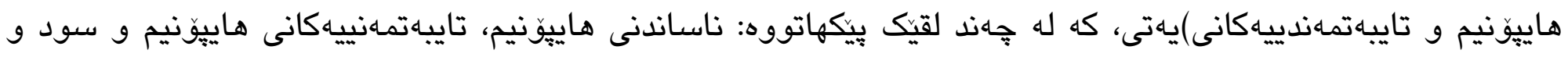
زيانهكانى هاييخونيم. بهاشى دووهميش به ناونيشانى (هايِّونيم وهك دياردهى ئابوريكردن له زماندا)، كه لهم لقانه يُّكهاتووه: دياردهى

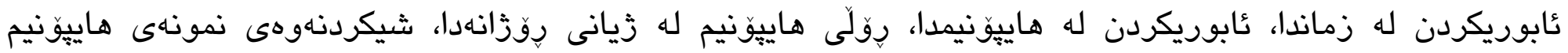
بهايوهست به نابوريكردناوه. كايله وشُشكان: هاييّونيم،دايِّين، واتاى تايبهتى، واتاى كثتى. 
ثابورى، وهك دياردهيهك پِهلويوّى بو زوّربهى لايهنهانى زيان كيثاوه، زمانيش ياكيكه لهو بوارانهى لهم دياردهيه بهدهر نييه، كه له ديّر زهمانهوه زمان به ئارِاستهى كورتكردنهوه و عابوريكردندا كاردهكات، هـروهها قوناغ به قوناغ بهرهو

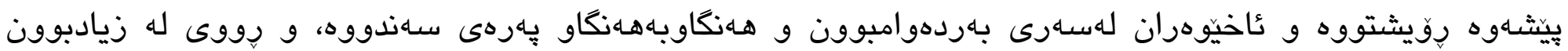
كردووه، جونكه به كهمترين كات و كهمترين وزه زورترين بير دهكهيهنريته لايهنى بهرانبهر. ئابوريكردن له زماندا تهنيا له يهك ئاستدا رهنكى نهداوهتهوه، بهلكو له كَثت ئاستهاندا خوّى دهبينيتهوه.

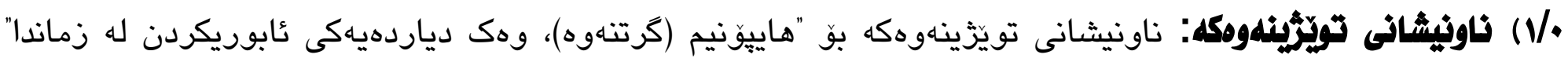

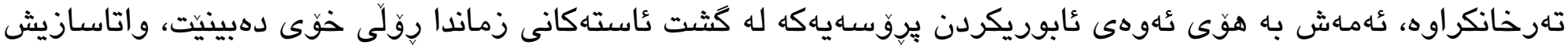

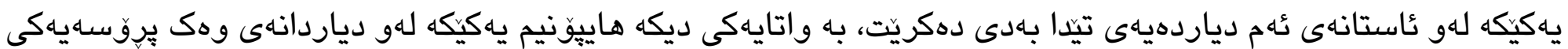

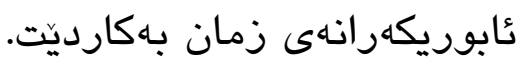

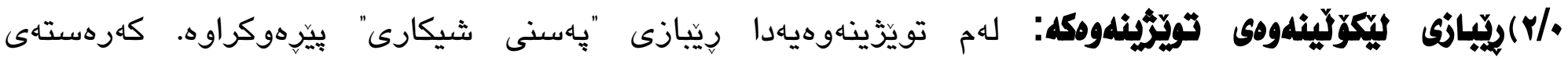
ليكولينهوهكهش له زمانى كوردى - شيّوهزارى سليمانى - وهركيراوه.

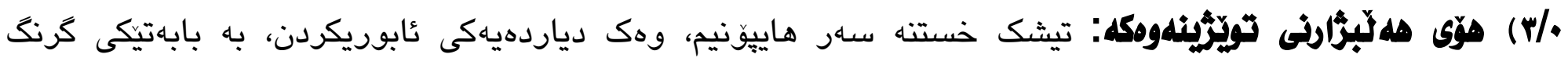

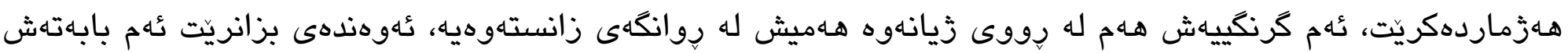

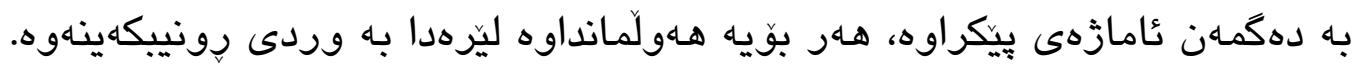

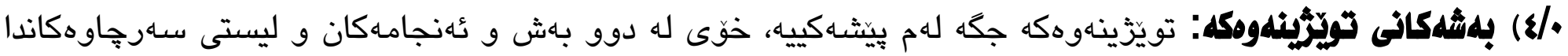
دهبينيتهوه:

بهشى يهكهم: به ناونيشانى "هاييّونيم و تايبهتمـهندييهكانى"، كه له جههند لقيك بِيكهاتووه:

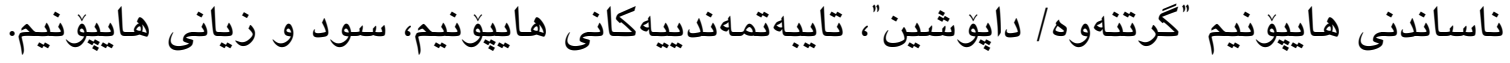

بهثى دووهميش به ناونيشانى "هاييونيم دياردهى ئابوريكردن له زماندا"يه، كه لهم لقانهى لاعى خوارهوه يِيكهاتووه: دياردهى ئابوريكردن له زماندا، ئابوريكردن له هايِّونيمدا، رِوّلى هاييّونيم له زيانى رِوّانهدا، شيكردنهوهى نمونهى هاييوّنيم پِّيوهست به نابوريكردنهوه. 


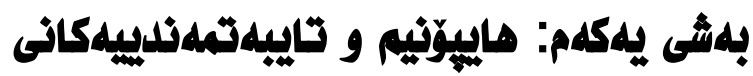

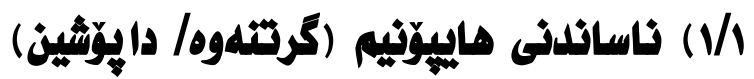

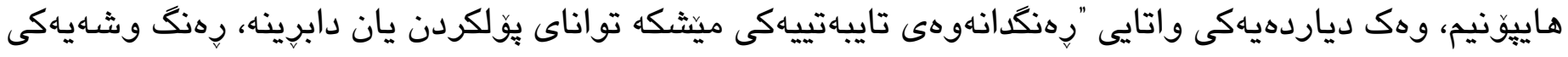

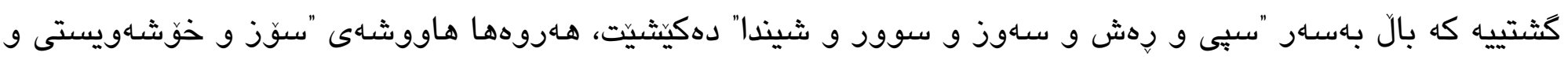

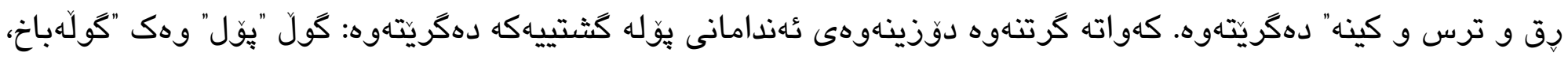

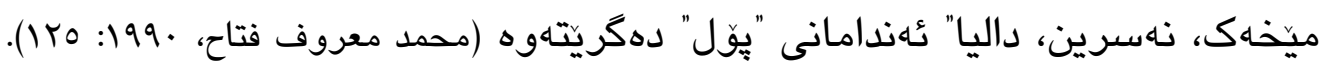
(لاينز)يش بهم جوره هايِوَنيم دهناسينيت و دهلِيت:

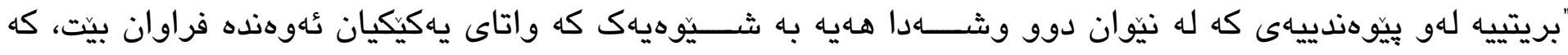
بتوانيت واتاى وشهكهى ديكهش بكريتّهوه" (كوروش سهفهوى، 7. ب. ب: 17). سهابارهت به ئهو بيّوهندييهى له هاييوّنيمدا هاهيه، ئهوا بريتييه له "يهاهوهندى كثتى به تايبهتهوه يان بريتييه لهو

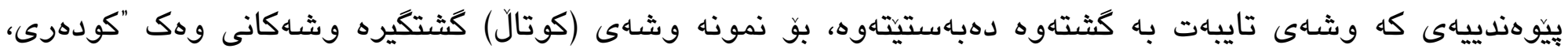

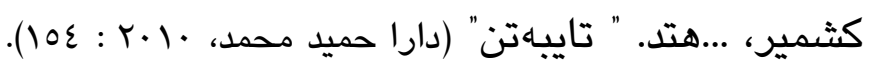

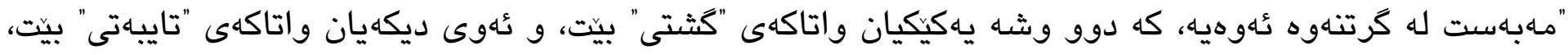

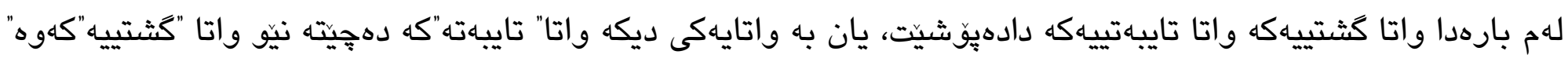

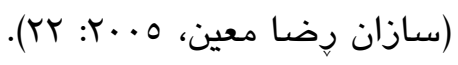

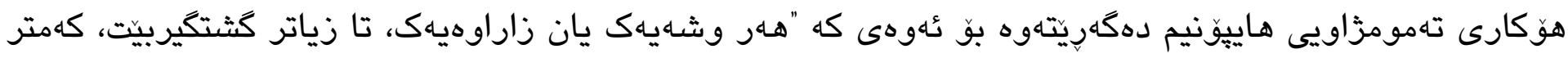

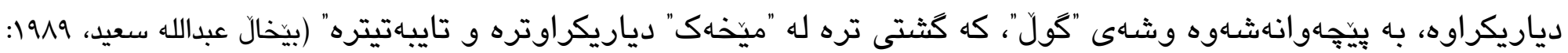

كرتنهوه وهك دياردهيهكى واتاسازى بيّوهنديى واتاى فهرهـنكييه، شانبهشانى دياردهكانى ديكهى وهك: هاوبيّزى و هاوواتايى و دزواتايى و فرهواتايى كاردهكات، "كه لهسهريككوه نزيكه له (هاووتا)، جونكه وشه كثتييهكه دهتوانيت شوينيى

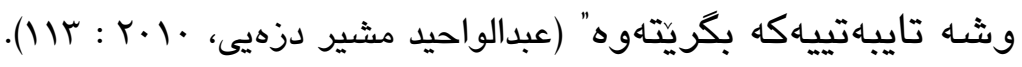

هاييونيم "دياردهيهكى بهربلاوه، له هاموو زمانيكدا هـهتى يِيدهكريت، ئهو لقهى زانستى واتاسازيش، كه بايهخ بهام

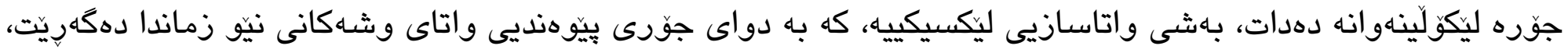
لهكَل وشهاكانى دهوروبهرى خوّيدا" (عبدالله عزيز محمد بابان ، ه...ب : (). 


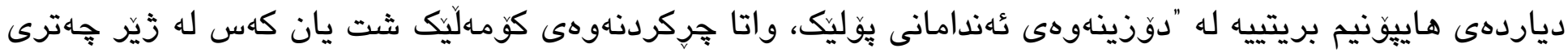

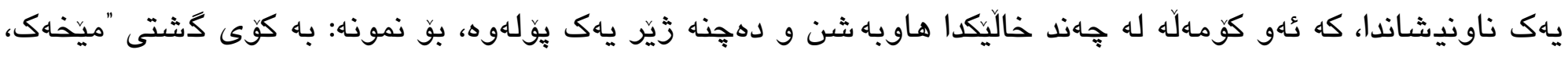

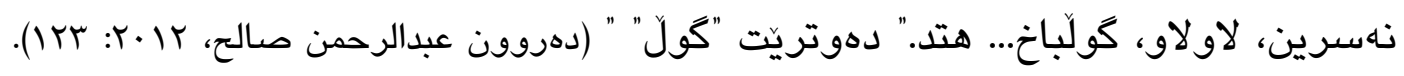

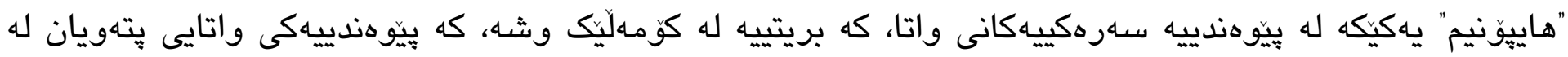

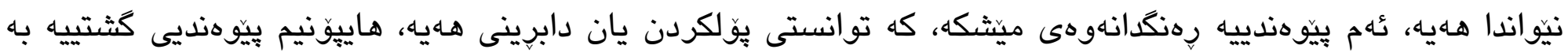

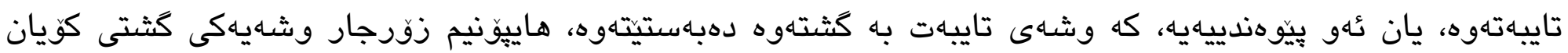
دهكاتهوه، يان ئهو كومهلّه وشهيه دهكريتهوه، كه به هاموويان بواريكى بيرى به خوّيانهوه دهبهاستيتهوه، هـروهها يّيّوهندييهكى واتايى ئاشكرا له نيّوانياندا هـيه، وهك وشهكانى "سبيى و سور و سكوز و ...هتد. "، كه له زيّر يهك وشهى كثتيدا كوردبنهوه ئهويش "رهنك"ه.

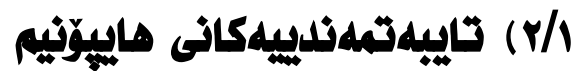

هاييوّنيم، وهك يهكيك له دياردهكانى واتاسازى جههند تايبهتمهندييهك لهخودهكريّت:

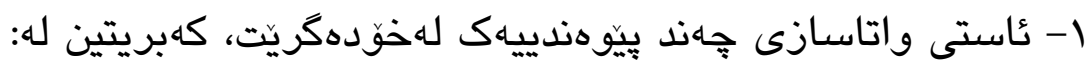

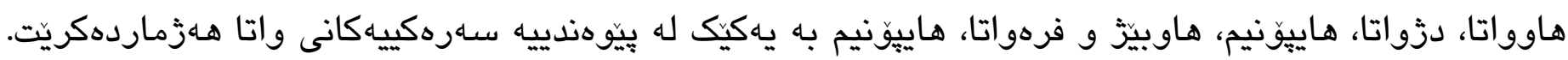

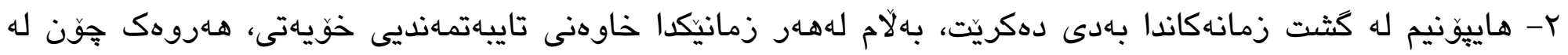

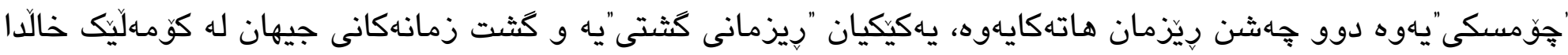

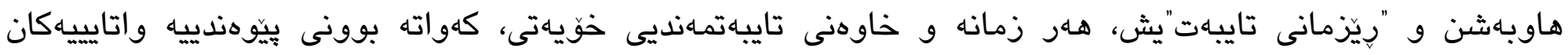

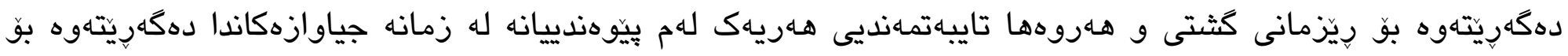

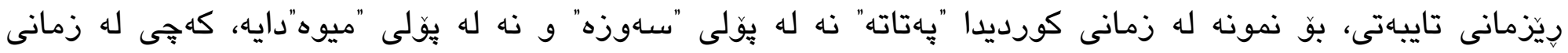

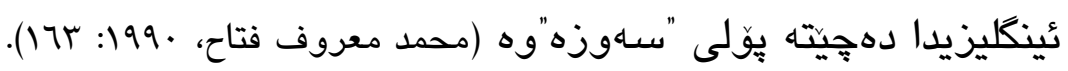

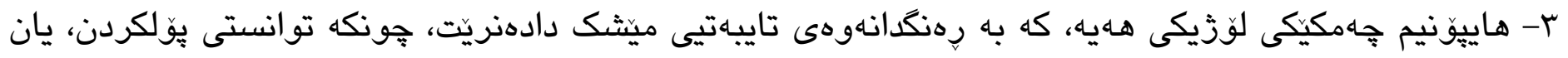
دابرينى هـايه.

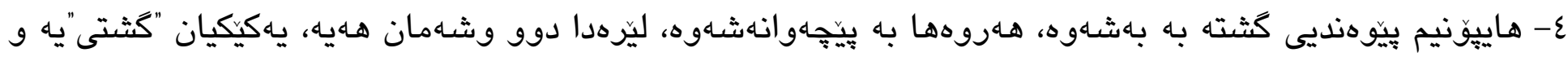

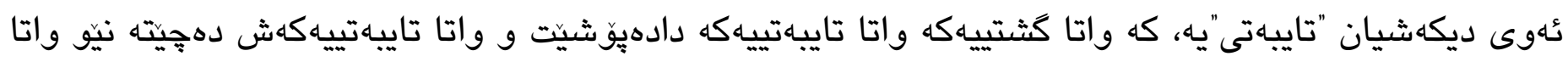
كثتييهكهوه.

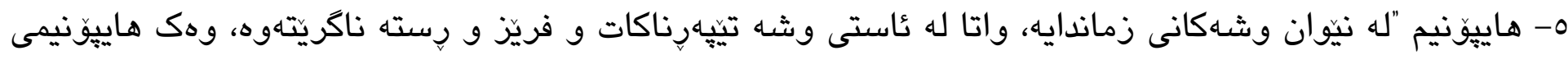

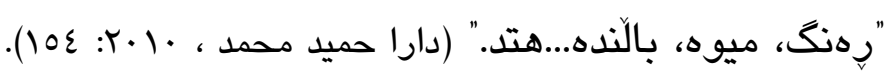


7- وشهكانى زمان دهبنه دوو بهش "سهرخان و زيّرخان"، سهرخان وشه كُشتييهكان و زيّرخان وشه تاييهتييهكانه،

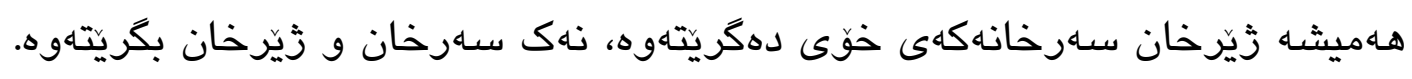

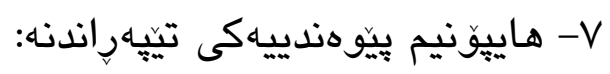

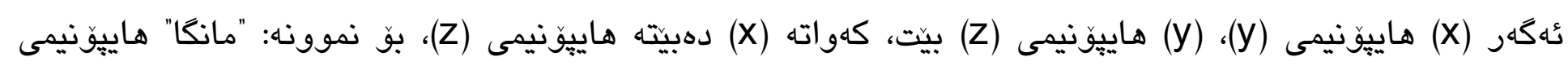

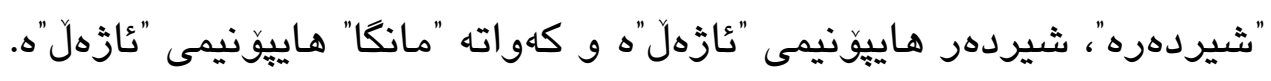

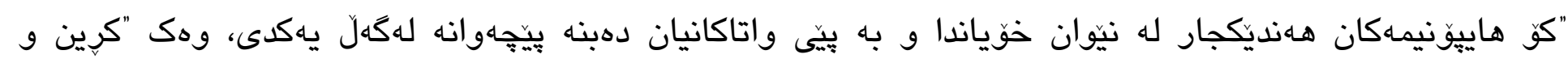

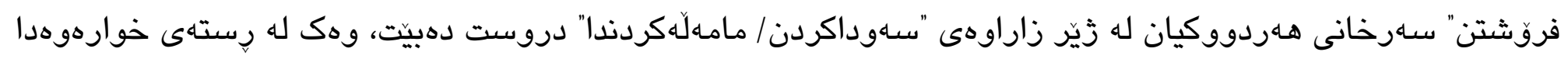

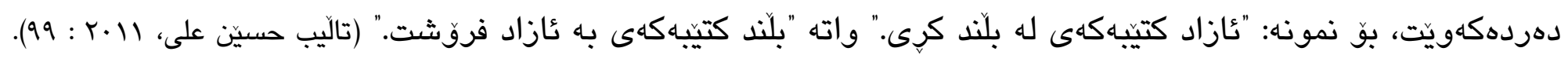

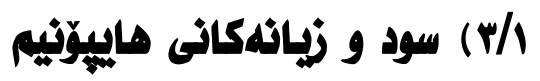

\section{1/\%//}

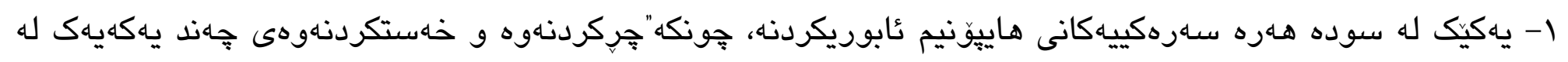

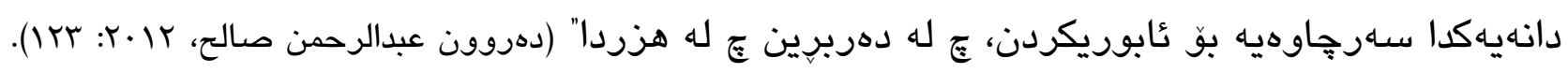
بوّ نمونه:

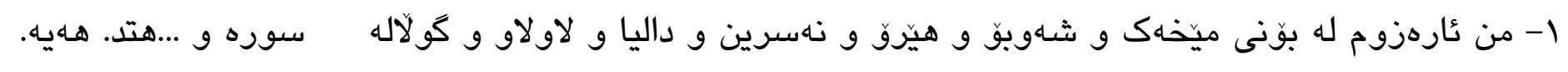

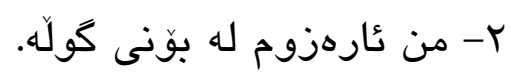

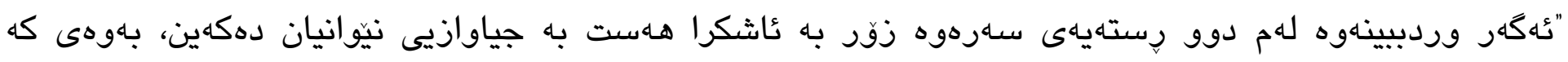

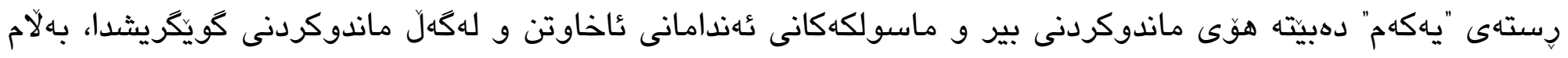

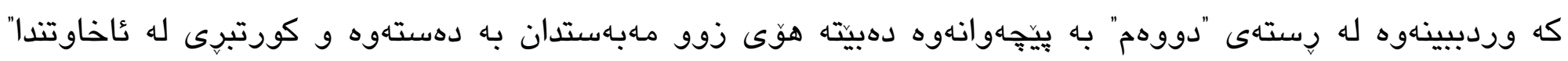

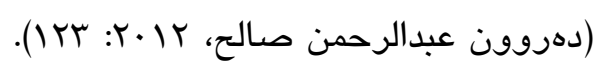

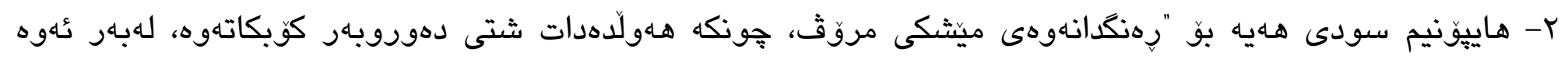

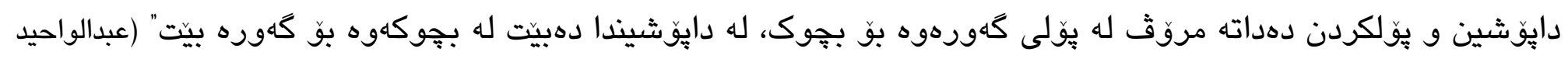

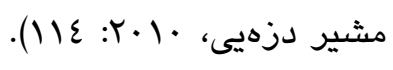




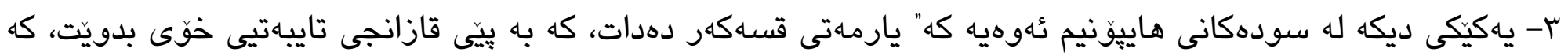

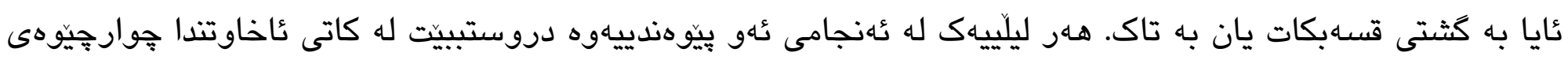

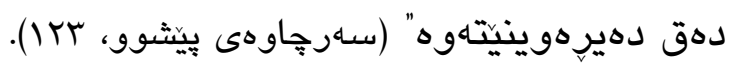

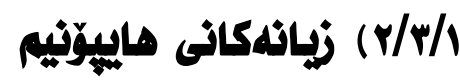

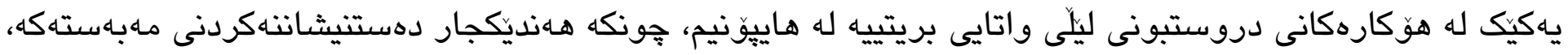

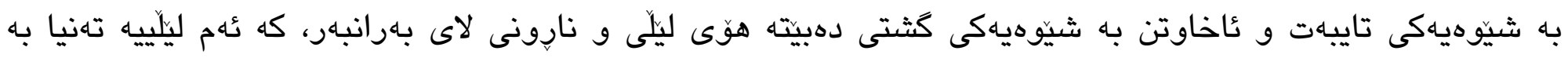

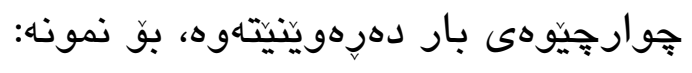
نمونهى ياككهم، كه دهليّين: ـ هـنديك له دراوسيِيهاكانمان بيزّاركهرن.

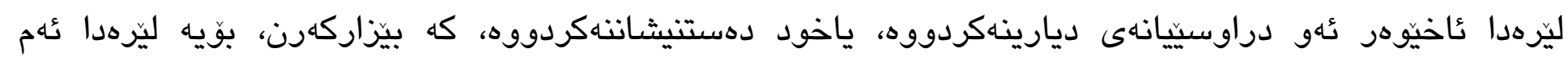

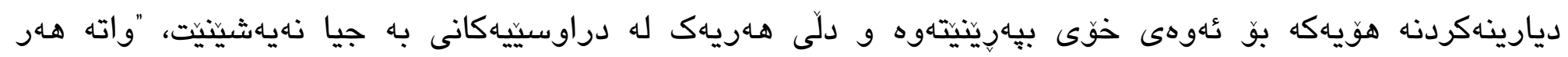

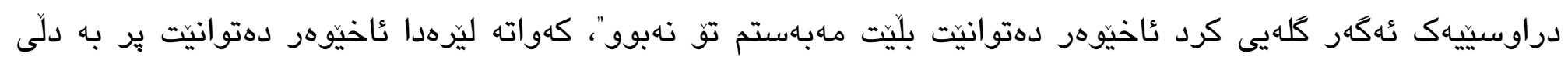

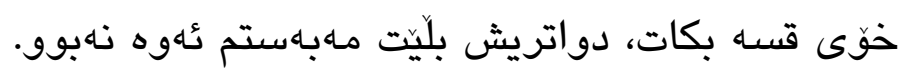

نمونهى دووهم:

- زوربهى خويّندكارانى قوناغى جوارهم يابهندنين به وانهانيانهوه.

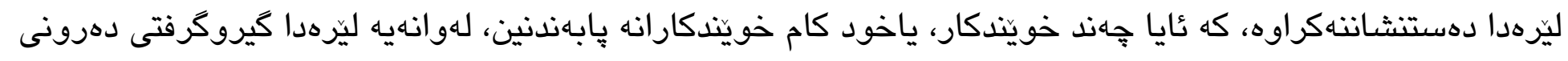

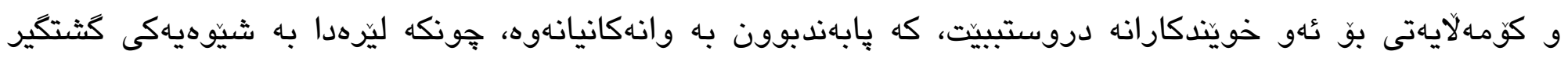
دهربارهى خويندكاران دواون. 


\section{بلهُ دوومم}

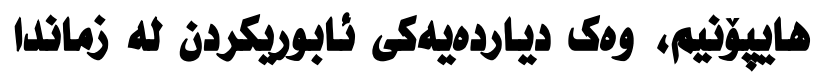

\section{r/1) دياردهى نابوريكردز له زماثلدا}

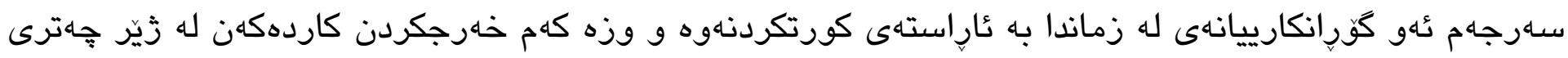

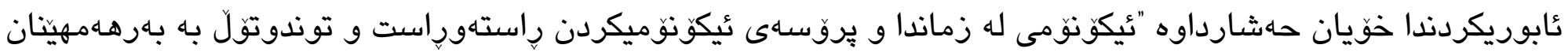

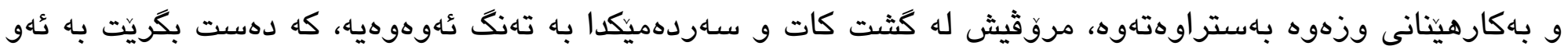

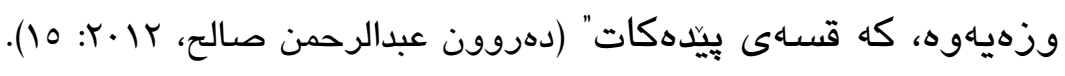

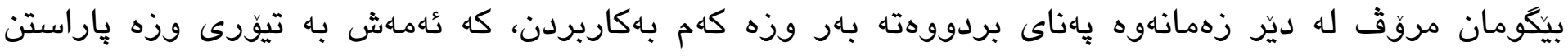

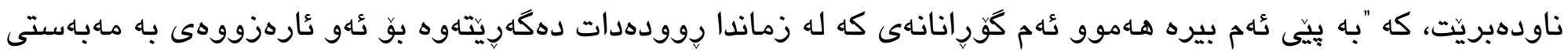

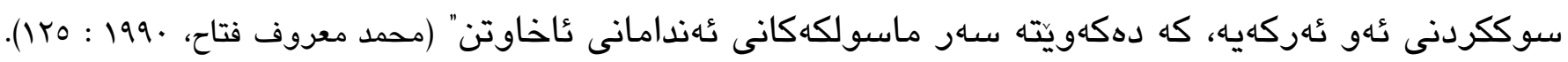

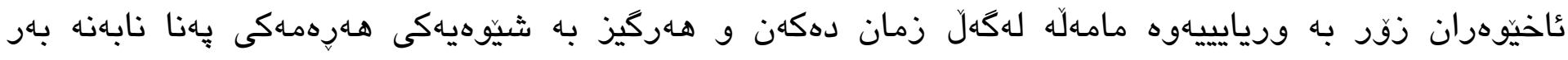

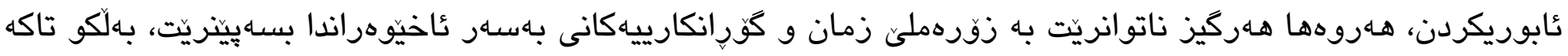

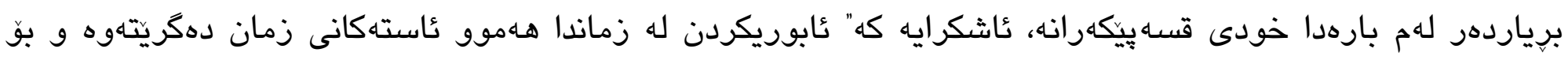

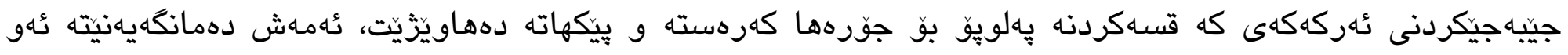

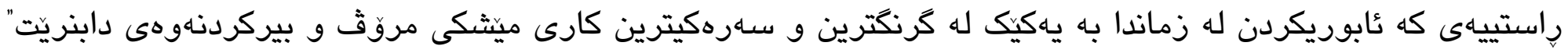
(سهرجاوهى يينشوو، 10).

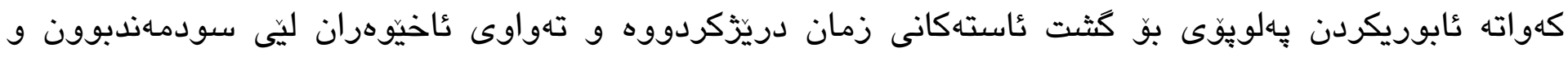

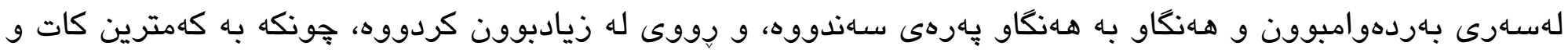
كهمترين وزه زورترين بير دهكهيهنريته لايهنى بهروانبهار. 


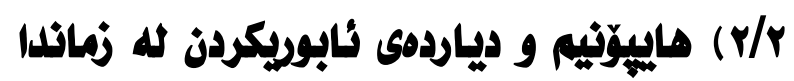

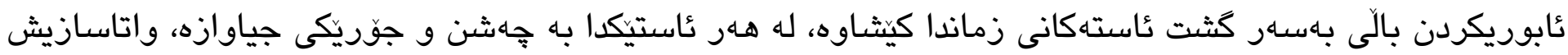

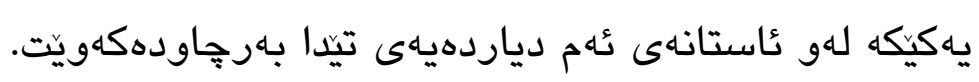

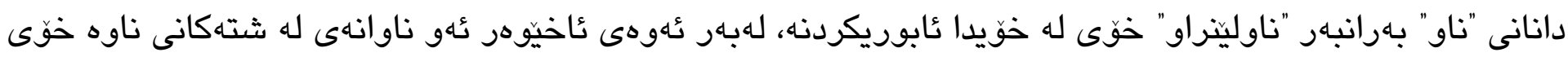

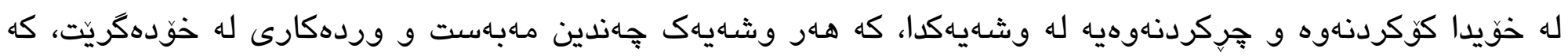

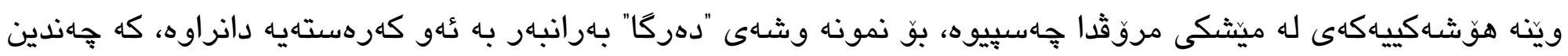

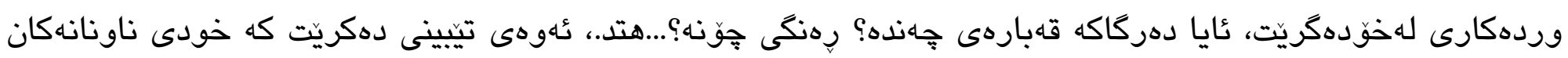

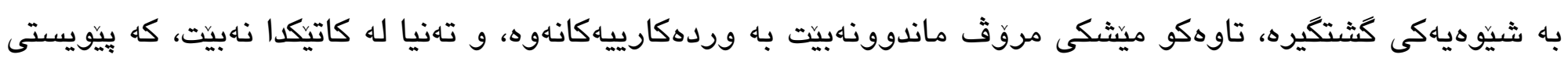

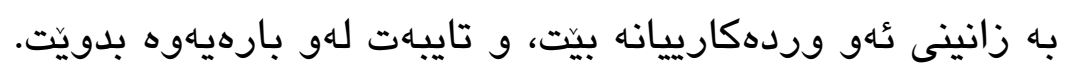

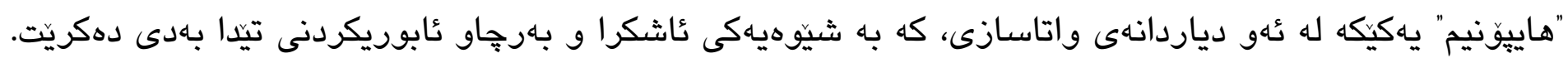

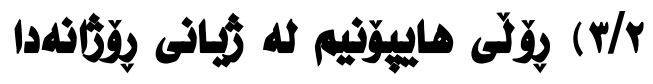

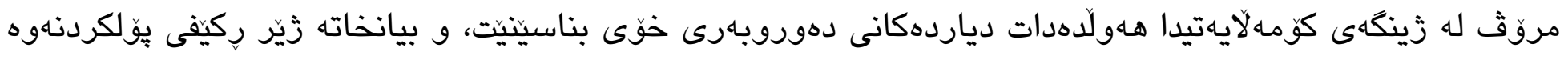

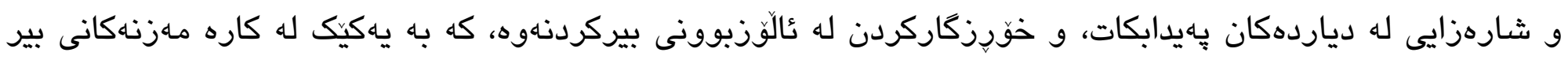

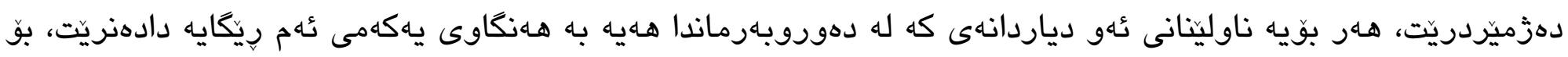

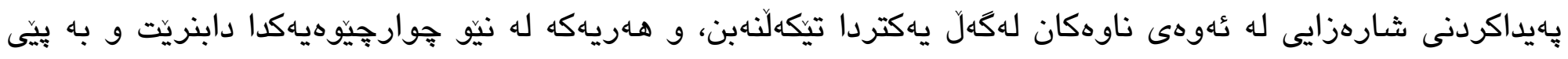

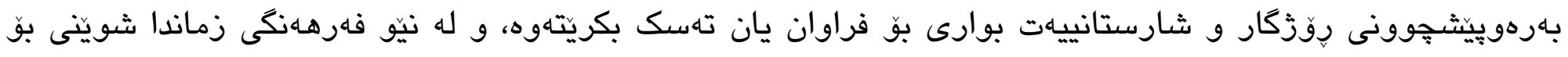

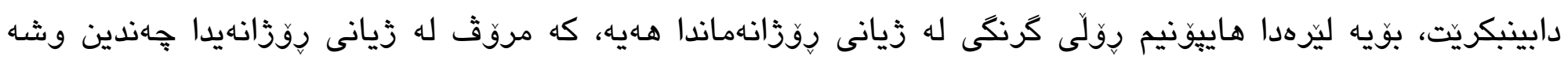

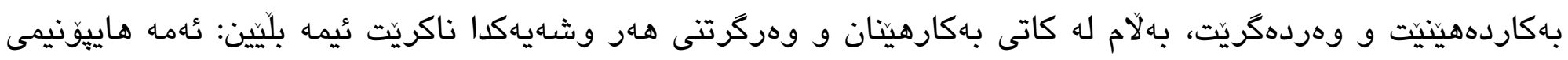

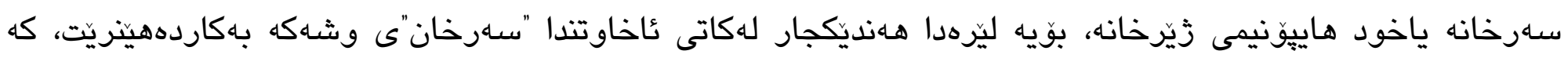

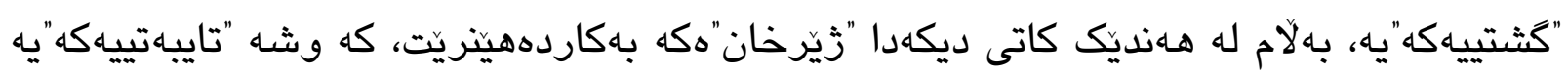

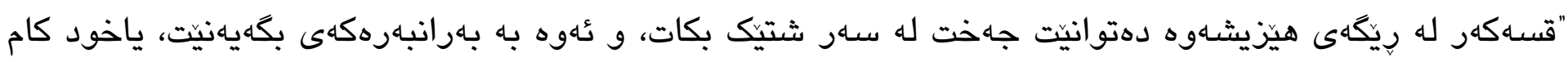

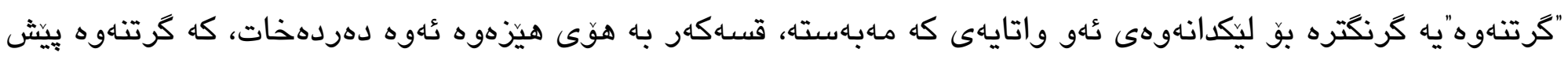

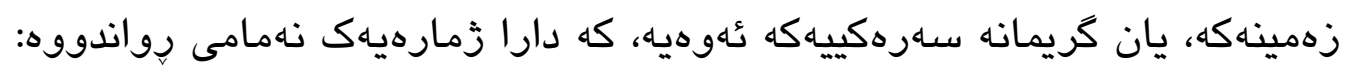

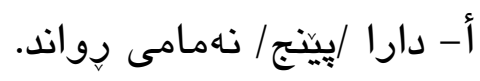

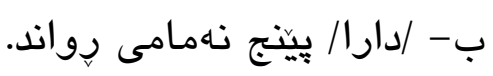


كه له رستهى (أ)دا قسهكهر به هوَى هيزّهوه ئهوه دهردهخات، كه كرتناهوه يِيش زهمينهكه يان كريمانه سهرهكييهكه

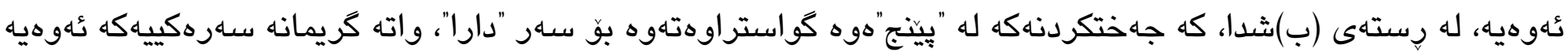

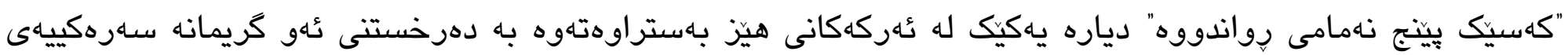

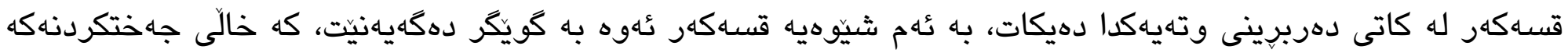

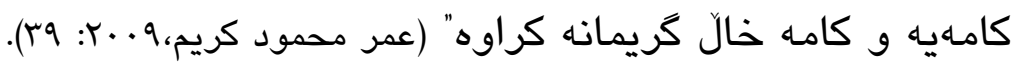

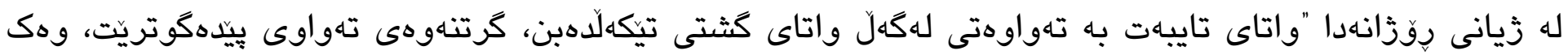

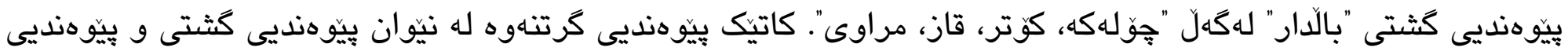

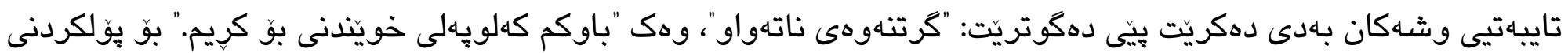

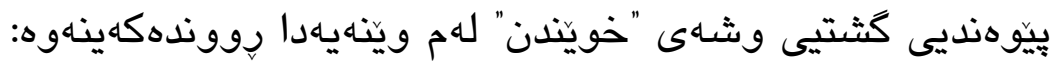

خويَندن
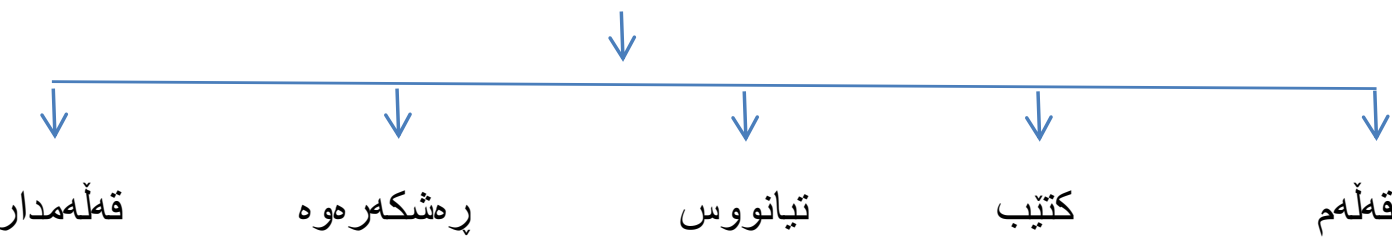

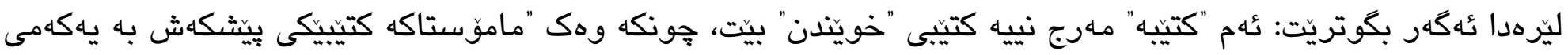

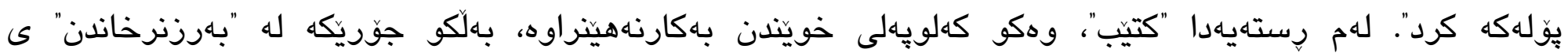

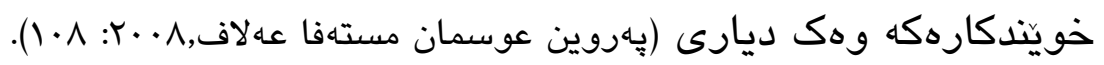

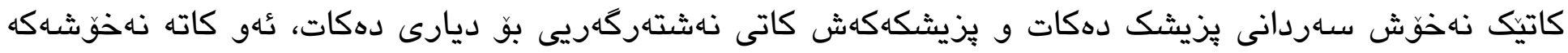
عاكاداردهاتهوه كه:

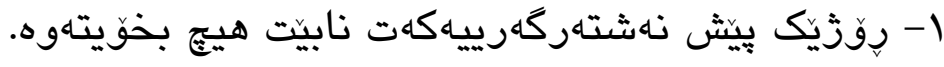

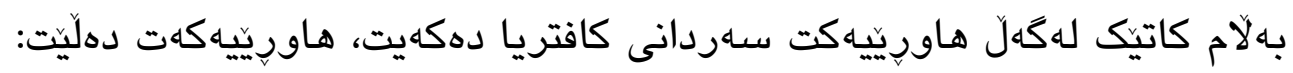
ب- نهوزاد ناخواتهوه، بهلام بيبسيهكى بوّ بهينها. ليّرهدا "خواردنهوه" له رستهى يهكهدا واتايهكى كثتيى هـهيه، بهلام له رستهى دووهمدا "خواردنهوه" واتاى تايبهتيى

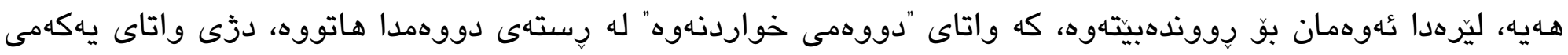

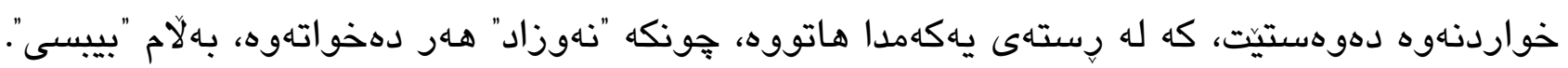

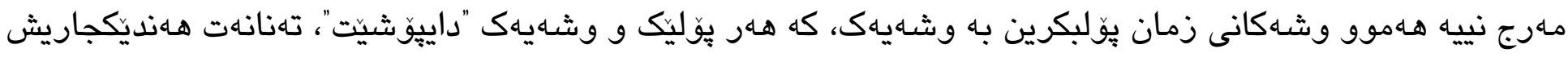

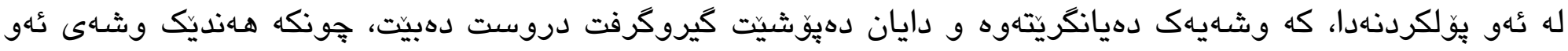




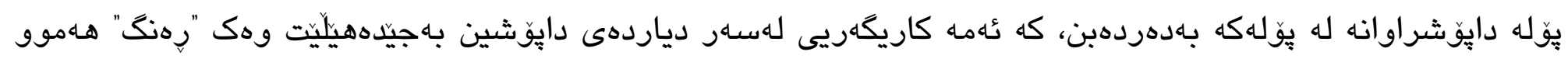

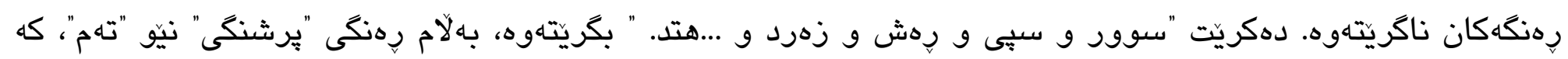

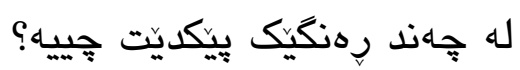

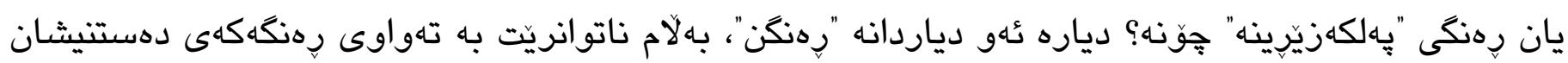

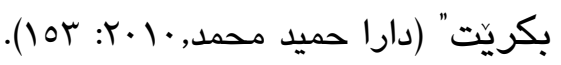

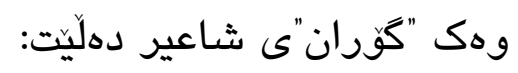
خورهى قهلّبهزهى كهف زيوينى جههم

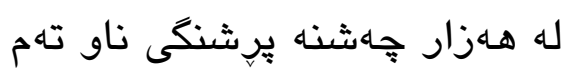

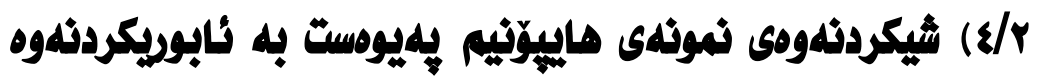

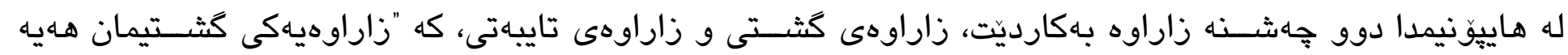

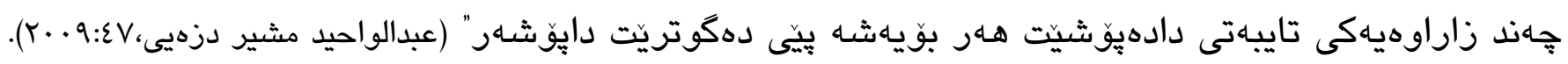

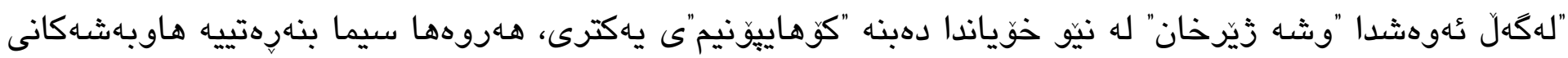

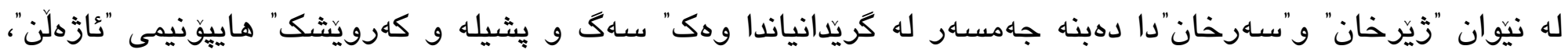

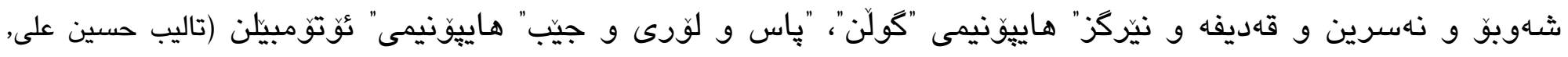
(99:

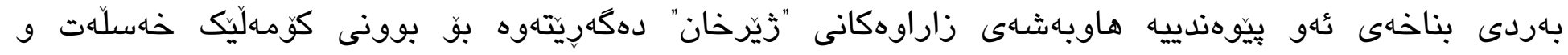

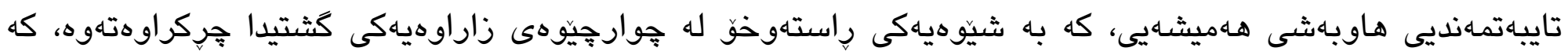

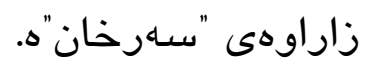

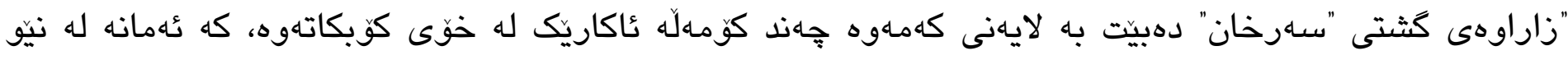

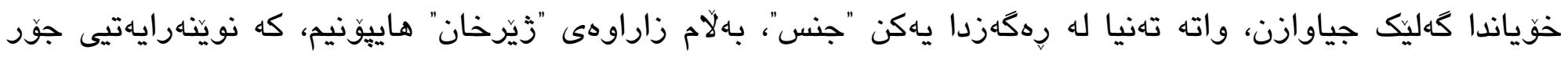

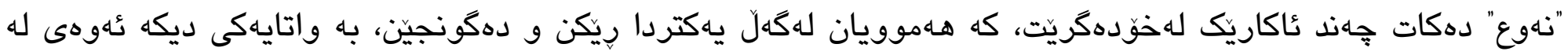




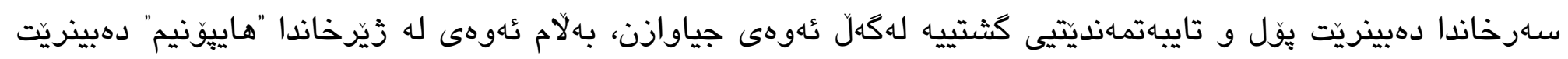

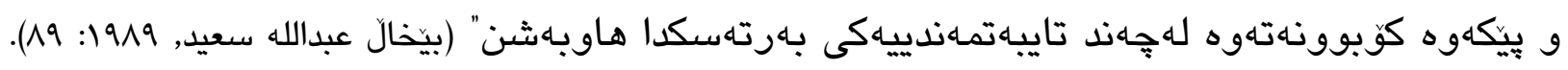

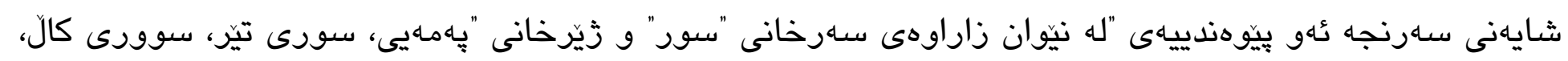

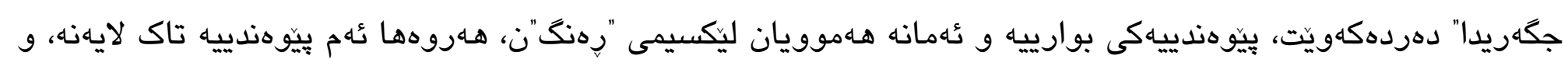

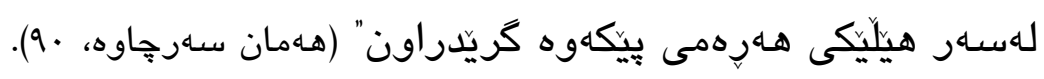

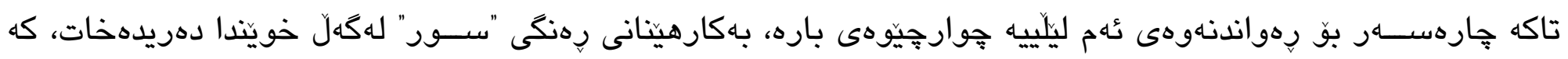

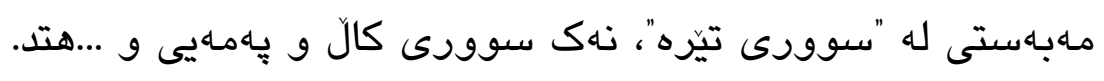

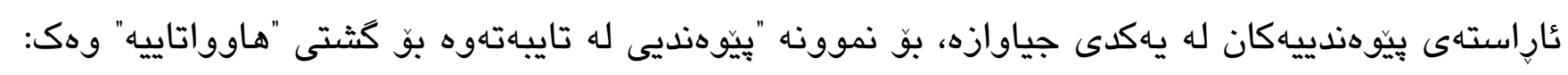

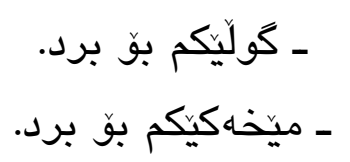

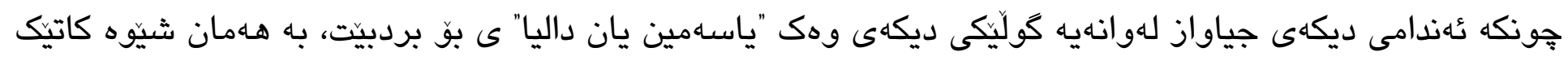

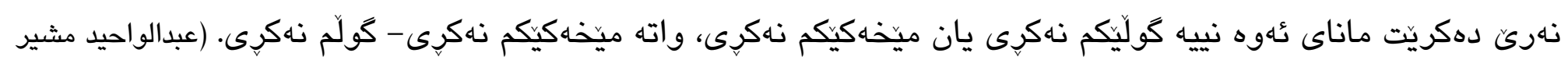
دزهيى, · •r: (1) (1). كوكردنهوه و جركردنهوهى جهاندين واتا و مـهبهست له زاراوهيهكدا، يهكيكه له تايبهتمهندييهكانى هايِّونيم، بو نمونه: ـ مندالّكهم له سهك دهترسيّ.

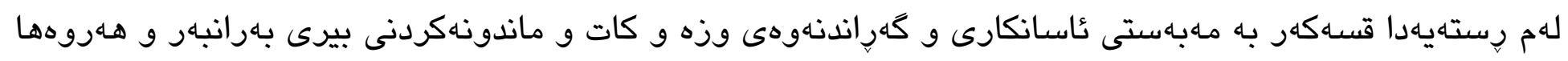

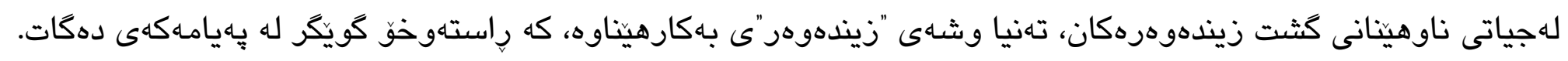

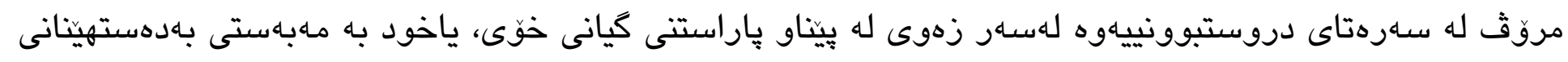

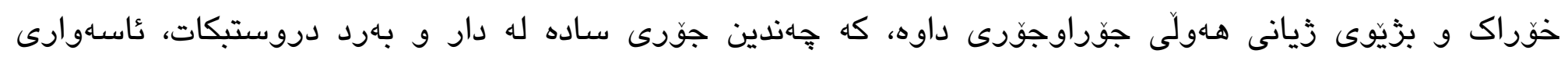

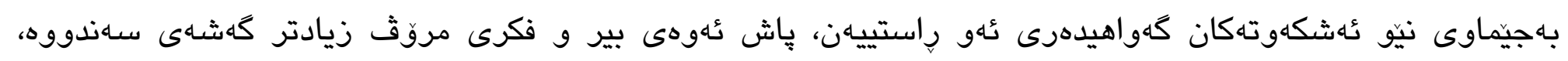

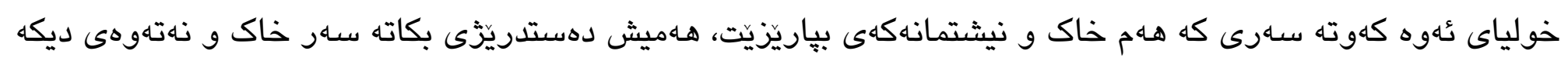
و داكيريان بكات.

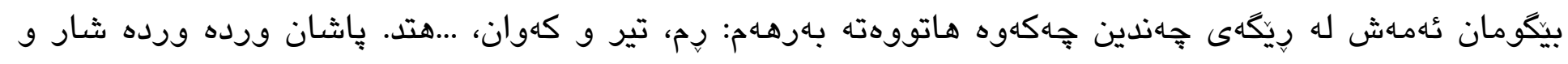

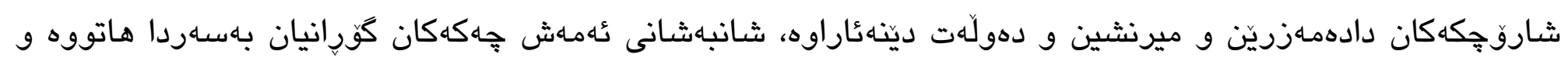

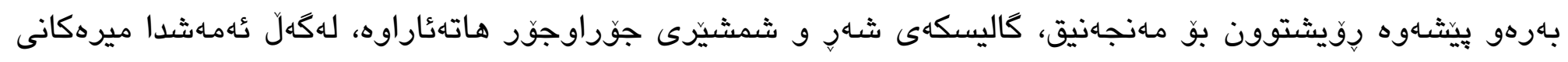

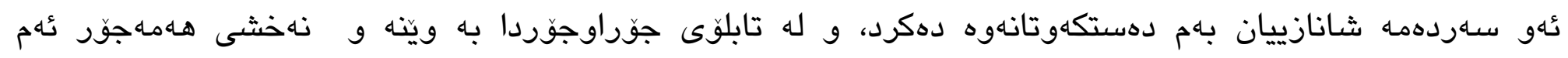




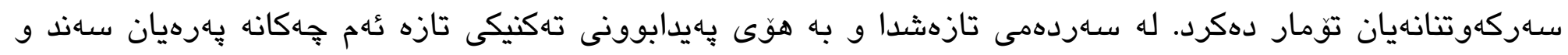

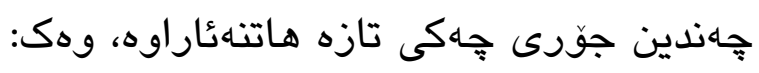

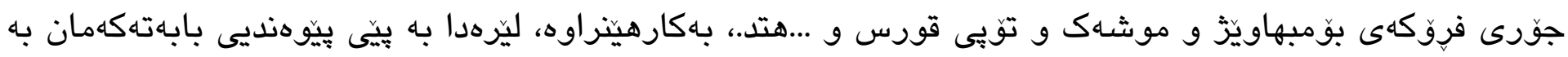

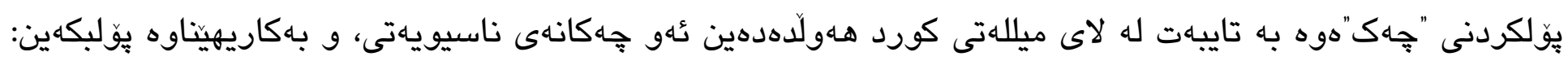
به شيّوهيهكى كثتى جهاكهان بهسهار سنى بواردا دابهش دهكهين: 1- جֶهكه سوكهكان ئهمانه بريتين له: " تير و كهوان، قوجّهقانى، كوتهك، رِم، نيّزه"

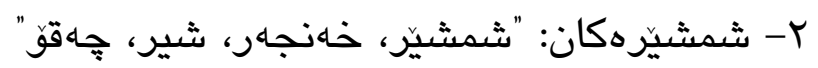

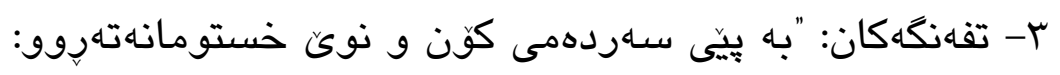

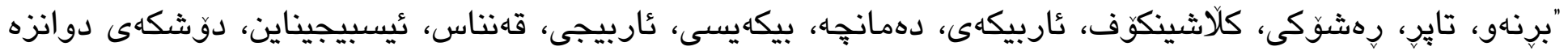

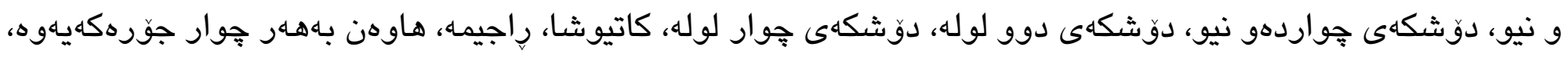
....هت.".

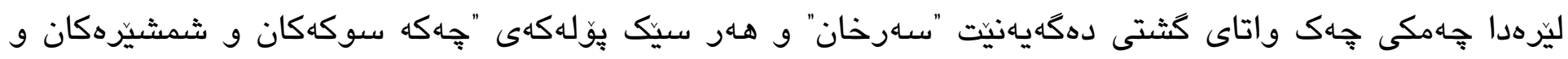

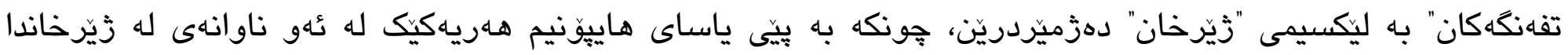

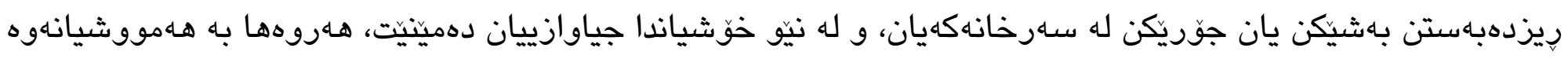

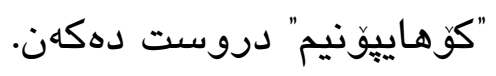




\section{تُلجزامهكان:}

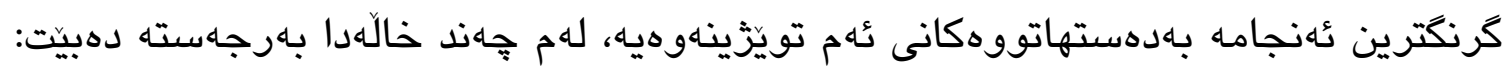

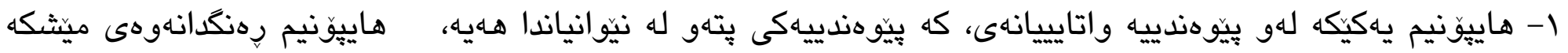

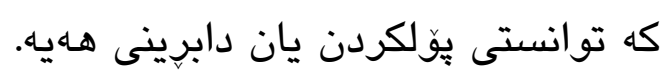

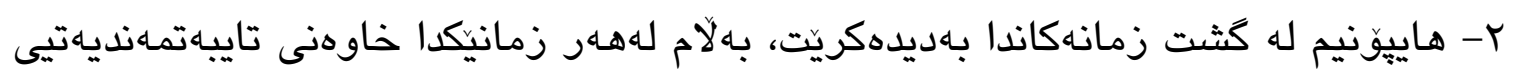
خوّياتى.

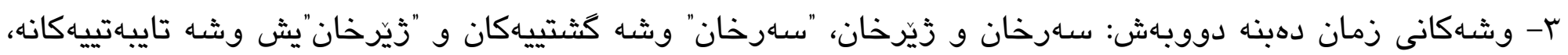

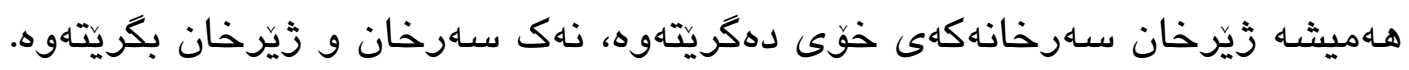

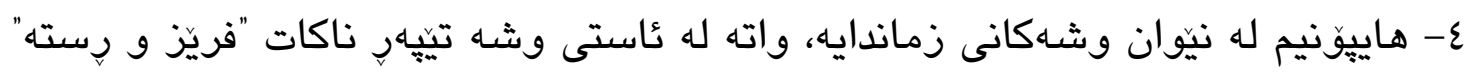
ناكريتهوه.

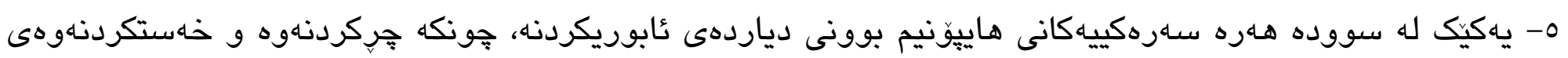

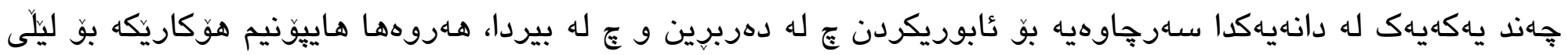

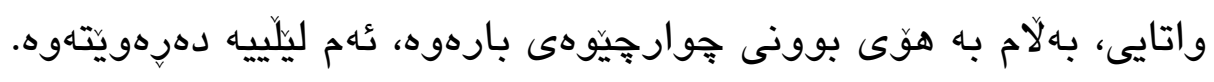




\title{
Hyponym As A Phenomenon In The Economy of Language
}

\author{
Salih Abdulla Babkr \\ Department of Chemistry, College of Science, University of Raparin, Rania, Kurdistan Region, Iraq. \\ E-mail: salh.abdulla@uor.edu.krd
}

\begin{abstract}
:
This research entitled "Hyponym as a phenomenon in the economy of language" deals with this linguistic term. The economy of language is a process that transcends the limits of all linguistic levels, and semantics is one of those levels in which this economic phenomenon is manifested. Hyponymy is one of the semantic relationships in which the phenomenon of linguistic economy occurs. Since it refers to the condensation of several things in one thing, this term (hyponym) has an active presence in all languages, nevertheless, it has special characteristics in each language.

The current research implemented the descriptive analytical method, using the Sulaymaniyah dialect as the main source of data. The study comprises an introduction, two sections, results and list of references.

As for the first section, which came under the title (Hyponym and its Characteristics), it dealt with several issues, including: Definition of the term (Hyponym), its properties, the benefits and disadvantages of Hyponym.

As for the second section which is entitled (Hyponym - Phenomenon in the Economy of Language), several issues were discussed in it: the phenomenon of economy in language, economy in (hyponym), the role of (hyponym) in daily life, and finally analyzing hyponym examples related to language economy.
\end{abstract}

Key Words: Hyponym, Innumerable, Cover up, Privet Meaning, General Meaning. 


\section{سله رجاومكان}

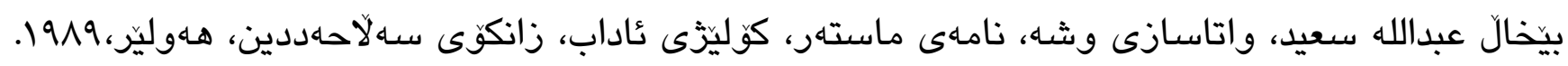

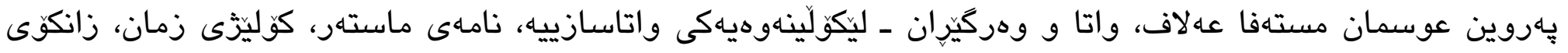

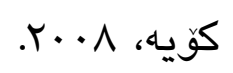

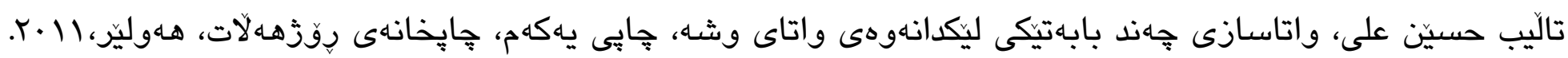

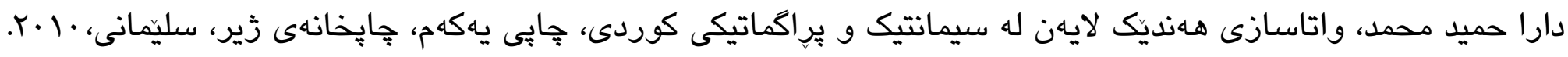

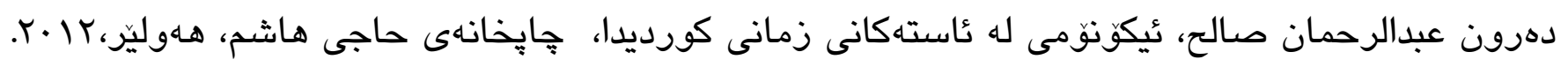

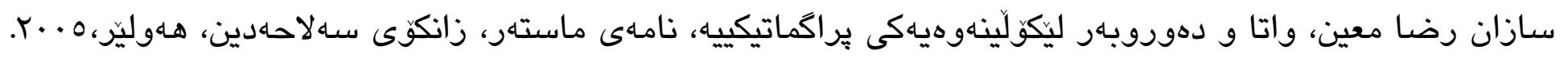

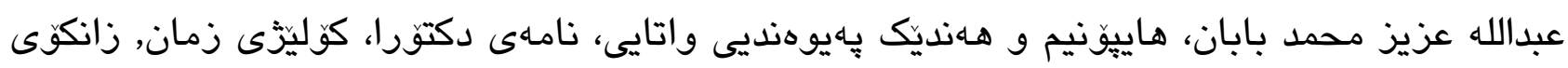

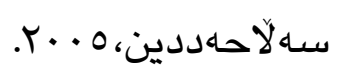

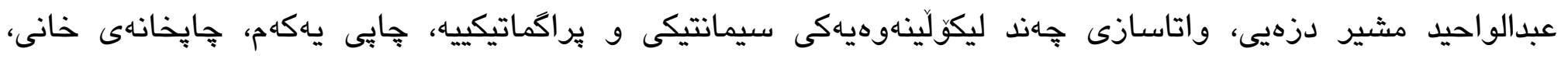

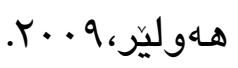

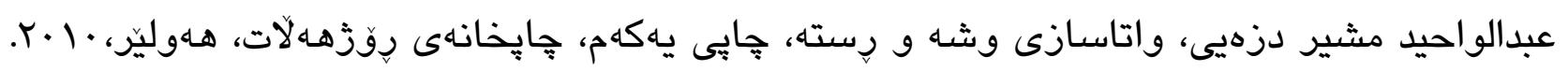

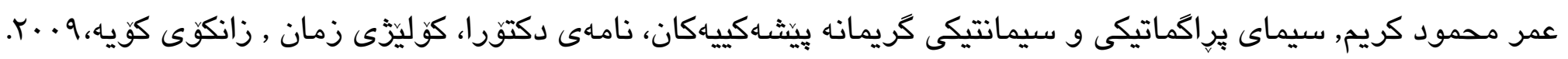

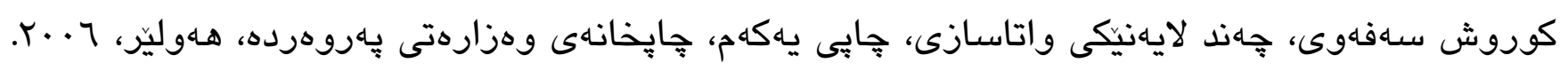
محمد معروف فتاح، زمانهوانى، هـوليزر، ·199. 